\section{Australian Genomics}

\section{Integrating genomic testing into healthcare}

\begin{tabular}{|c|c|c|}
\hline $\begin{array}{l}\text { Over the past few years, } \\
\text { researchers have developed } \\
\text { many new techniques to } \\
\text { collect information from our } \\
\text { genome. This can help identify } \\
\text { inherited conditions and some } \\
\text { types of cancer, for example. } \\
\text { However, these methods have } \\
\text { often been kept within the } \\
\text { limits of scientific research. } \\
\text { Now, Australian Genomics is } \\
\text { keen to push their use into } \\
\text { a clinical setting, where they } \\
\text { can benefit more patients and } \\
\text { their families. }\end{array}$ & $\begin{array}{l}\text { ess than ten years ago, genomic } \\
\text { sequencing was restricted to } \\
\text { the realms of scientific research. } \\
\text { Today, methods are getting easier } \\
\text { and cheaper, and the technology is } \\
\text { finally being applied widely in a clinical } \\
\text { setting. Some estimates state that it has } \\
\text { the power to help more than } 60 \text { million } \\
\text { people over the next few years. } \\
\text { Given the potential benefits, it is not } \\
\text { surprising that many governments are } \\
\text { eager to support its implementation } \\
\text { into healthcare systems. At the moment, } \\
\text { over } 20 \text { countries around the world } \\
\text { have invested a total of US } \$ \text { billion } \\
\text { to establish large-scale initiatives to } \\
\text { promote the transition from research } \\
\text { centres to mainstream medical } \\
\text { practices. } \\
\text { Despite this money injection, } \\
\text { implementing genomic medicine on } \\
\text { a large scale is a complex issue. It is } \\
\text { one thing to use these methods in } \\
\text { a single institution, or even in } \\
\text { multiple organisations with } \\
\text { close links, but applying } \\
\text { the same principles to } \\
\text { a whole healthcare } \\
\text { system requires an } \\
\text { entirely different } \\
\text { approach. }\end{array}$ & $\begin{array}{l}\text { Professor Kathryn North, requires a co- } \\
\text { ordinated, whole-of-nation approach. } \\
\text { AUSTRALIAN GENOMICS } \\
\text { The Australian solution came in } \\
\text { the form of a new nationwide } \\
\text { network called Australian Genomics. } \\
\text { Established in } 2014 \text {, it includes more } \\
\text { than } 80 \text { organisations from research } \\
\text { and academic groups, to diagnostic } \\
\text { laboratories and clinical services, } \\
\text { located across all six states and two } \\
\text { territories. In the following year it } \\
\text { was awarded AUD } \$ 25 \text { million by the } \\
\text { National Health and Medical Research } \\
\text { Council to analyse the challenges } \\
\text { and opportunities related to the } \\
\text { integration of genomic medicine into } \\
\text { the Australian healthcare system. } \\
\text { On the plus side, the study identified } \\
\text { several research and clinical centres } \\
\text { ahead of the game. These groups } \\
\text { were already collecting samples } \\
\text { from their patients and performing } \\
\text { genomic testing to identify specific } \\
\text { conditions. In contrast, the federated } \\
\text { model of healthcare between state and } \\
\text { federal governments was identified } \\
\text { as a challenge potentially leading to } \\
\text { duplication of effort and inefficient use } \\
\text { of resources. } \\
\text { BUILDING NATIONAL CLINICAL } \\
\text { AND RESEARCH NETWORKS: } \\
\text { FLAGSHIP PROJECTS } \\
\text { At its inception, Australian Genomics } \\
\text { established flagship projects - } \\
\text { prospective clinical studies interrogating } \\
\text { different genetic disorders - to evaluate } \\
\text { how to deliver genomisc in healthcare } \\
\text { in different clinical settings. In the past } \\
\text { five years } 21 \text { rare disease and cancer } \\
\text { flagships have been launched across } 32 \\
\text { clinical sites. Many of those have wound } \\
\text { down, but new projects have launched } \\
\text { under another national funding scheme. } \\
\text { All projects continue to use an entire } \\
\text { network of scientists, clinicians and } \\
\text { genetic counsellors dispersed across the }\end{array}$ \\
\hline
\end{tabular}

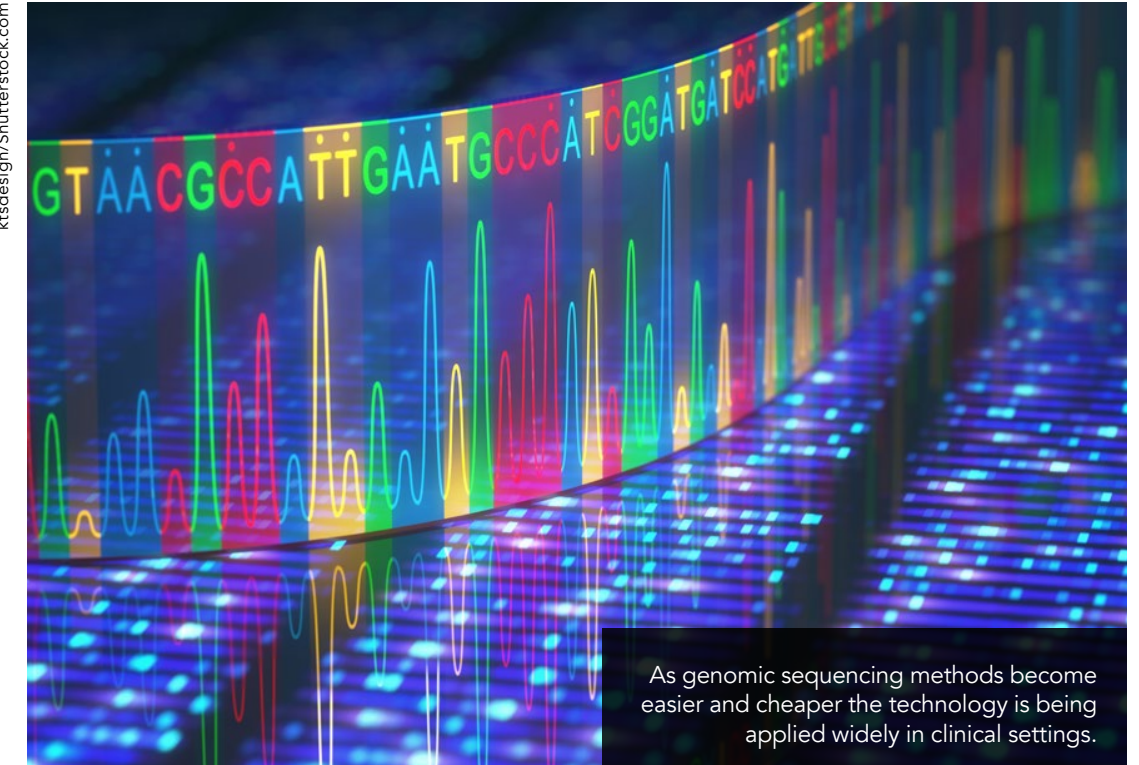

country to maximise available resources The main aim is to recruit patients for genomic testing in specific diseases, to

approach has the potential not only to make rapid diagnosis a reality in intensive care, but also to substantially reduce overall costs. Critically, it can be

life-changing for the patient and their

infrastructure for a nationally-consistent approach to the use of genomic programmes span i) workforce and education, ii) policy and ethics, iii) data federation and analysis, and iv a national diagnostic network, and engage a wide range of expertise including data specialists, lawyers, economists, policy analysts and educators - the disciplines that will underpin effective implementation.

Although clinical genomic testing is still done exclusively in accredited laboratories, Australian Genomics has embraced the task of assessing curre practices and developing a national approach to how consent is discussed with patients, as well as designing pey prio ity is to establish standatised data storage and management solutions for the immense amount of data generated during genomic \begin{tabular}{lll}
$\begin{array}{l}\text { access to clinical } \\
\text { trials. These }\end{array}$ All of these large-scale initiatives have & $\begin{array}{l}\text { its flagship projects. } \\
\text { Australian Genomics }\end{array}$ \\
\hline
\end{tabular} projects also projects also to assess the impact of genomic medicine,

including how

much it costs to carry out testing and how easy and accurate it is to reach a diagnosis. In technica terms researchers and cliniciens have a variety of tools at their disposal, including whole genome mitochondrial and RNA sequencing.

One study for example is using genomic sequencing to diagnose children in intensive care. The pilot study of over 100 infants and childre from various sites in Australia showed that it is possible to use a national and highly-coordinated genomic diagnosis programme to provide ultra-rapid diagnoses for these children; doctors were able to identify more than half of the children's conditions, and in just three days. It's an ambitious and novel approach - a world first in conducting ultra-rapid rare disease diagnosis across multiple centres over a significanty

\section{systems by integrating genomic} technologies into clinical care.

family who, once having a diagnosis, can plan their child's future health care. BUILDING THE FOUNDATIONAL MUEOMIC MEDICINE

Running in parallel to the flagship projects are four programmes of work projects are four programmes of work
that are building the foundational

also brings together experts in health economics, ethics and law to develop new policies and clinical practices

adapted to genomic testing. All programmes also focus on workforce needs, upskilling health professionals and identifying appropriate

In 2018 the Australian Government sent a further signal of its support for

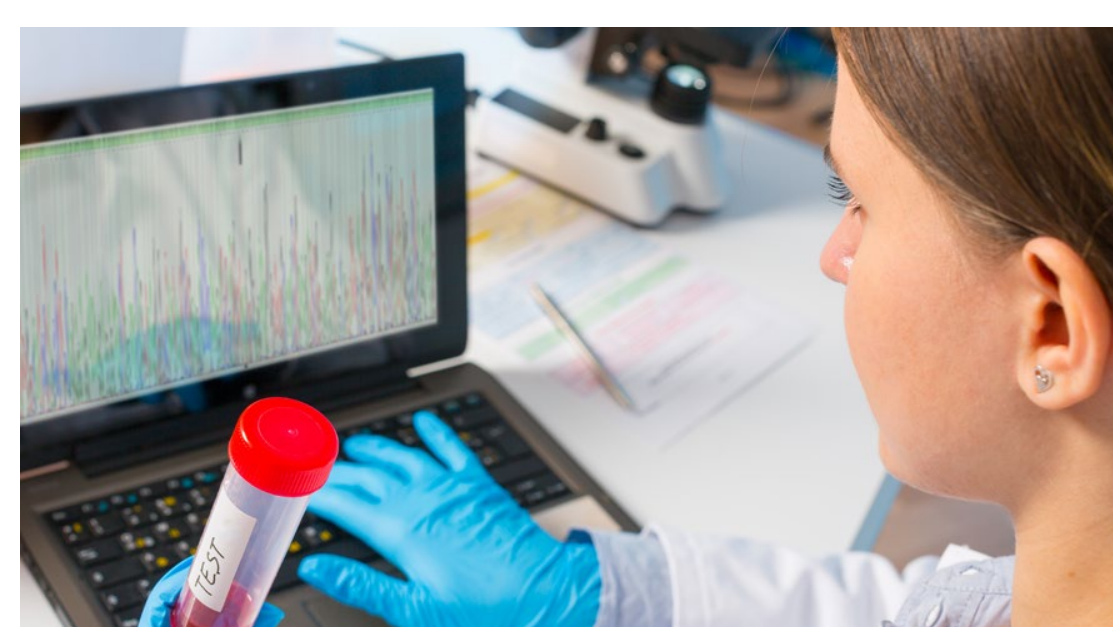




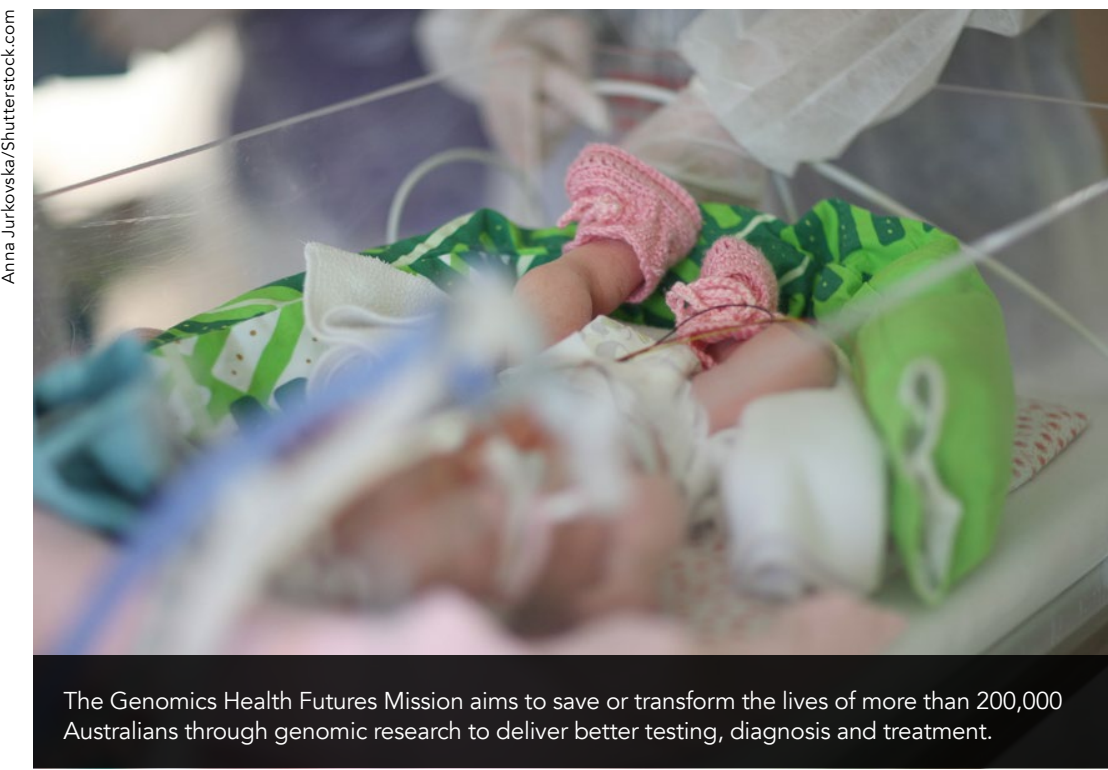

Australian Genomics believes it has a responsibility to fast-track the implementation of genomic medicine and deliver its benefits to patients and their families.

it committed AUD $\$ 500$ million over 10 years to a new entity, the Genomics Health Futures Mission. The GHFM builds on existing research and fund new projects such as the AUD $\$ 20$ million reproductive genetic carrier screening study, Mackenzie's Mission which is administered by Australian Genomics. The carrier screening study is expected to pave the way for the carrier screening nationally.

INTERNATIONAL PARTNERS Australlian Genomics is a "drive project' of the Global Alliance for Genomics and Health (GA4GH). The main aim of the GA4GH is to develop technical standards and policies to allow the sharing of clinic and genomic data in a secure and ethical manner. As a driver project, Australian Genomics contributes to standards, testing them under real-

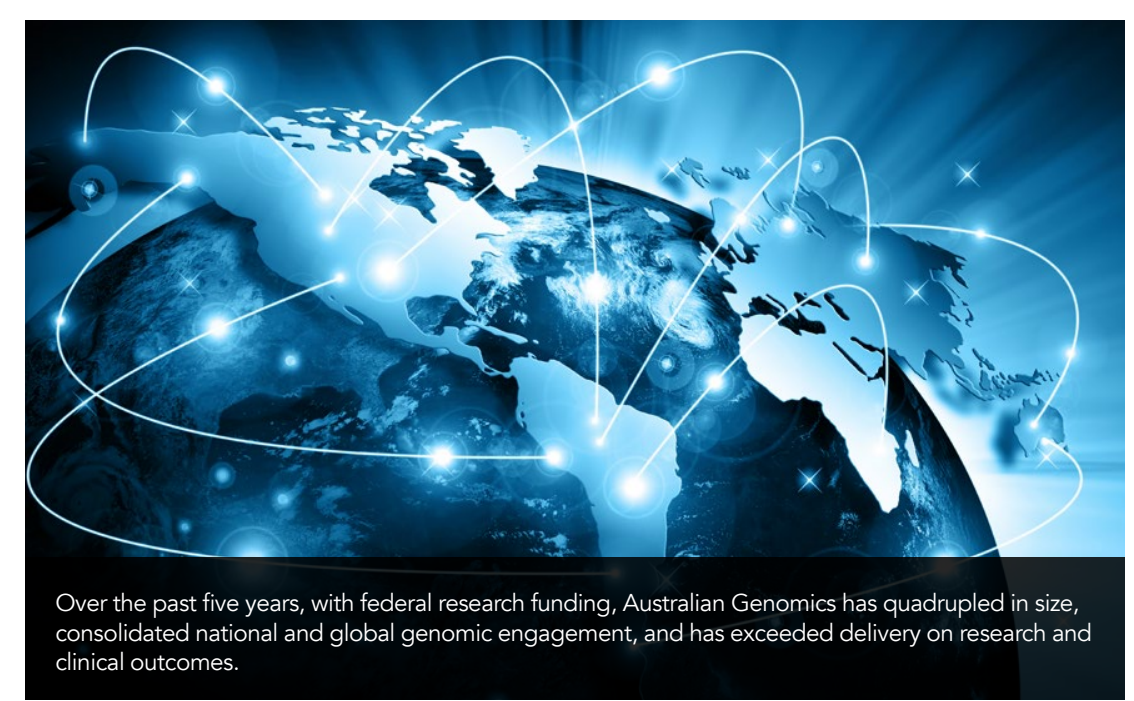

Ife conditions and supporting their dissemination in clinical settings.

The only way for there to be successful sharing of genomic data on a worldwide scale is to promote uniform capture, access and sharing. This has led to the establishment of Genomics in Health Implementation Forum which was developed by Genomics England and Australian Genomics as driver projects of the Global Alliance or Genomics and Health. The forum meetings bring together experts from more than 30 large scale initiatives around the world with a view to dentifying opportunities for in-depth collaboration and resource sharing. $I$. practical terms, the group is currently Working on a web resource to make different initiatives and list contoss details for specific areas, such as ethics

\section{BRIDGING THE GAP}

Over the past few years, Australian Genomics has built a national network with the ability to adapt to new procedures and promote the move from a research setting to clinical operations. Professor North says it is fostering an approach that brings basic genomic research and its clinica application much closer together.

It has not been easy to get to this stage, and the journey is only beginning. The hard part is going to routine clinical diagnosis, the same way bloos samples or X-rays are

done. Australian Genomics believes

thas a responsibility to fast-track the mplementation of genomic medicine and deliver its benefits to patients and their families.

Over the past five years, with federal esearch funding, Australian Genomics has quadrupled in size, consolidated national and global genomic engagement, and has exceeded delivery on research and clinical outcomes," says Professor North "We have proved that this approach works and that it can now be built up to support the rapid translation of

\section{Behind the Research}

Professor Kathryn North AC E: dorothy.illing@mcri.edu.au T: +61458549940 W: australiangenomics.org.au

\section{Research Objectives}

Taking genomic testing from the lab to the clinic, Australian Genomics is closing the gap between basic evidence to inform national halth policy as genomics .

\section{Detail}

Kathryn North

50 Flemington Road, Parkville VIC Australia

Bio

Professor Kathryn North AC is the Lead of Australian Genomics, Director of the Murdoch Children's Research Institute and Vice-Chair of the Global Alliance for Genomics and Health. She trained as a child neurologist and clinical geneticist, and has doctorates in neurogenetics and genomics. She chairs the Strat

Funding

- Austral Gearth and Medical Research Counci. - Australian Govenment's Medical Research

\section{Collaborators}

then than 80 partners and 400 collaborators. See more at: https://www.australiangenomics.org.au/partners/

\section{Australian Genomics} Health Alliance
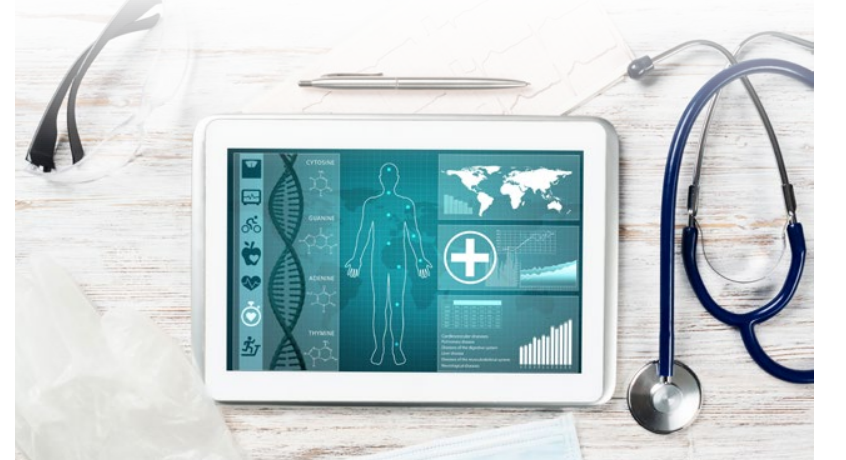

\section{References}

Stark Z, Boughtwood T, Phillips P, Christodoulou J, Hansen $D$, Braithwaite J, Newson A, Gaff C, Sinclair A, North $K$ (2019) Australian Genomics. A Federated Model for Integrating Genomics into Healthcare. The Americar Journal of Human Genetics, 105, 7-14

Stark Z, Dolman L, Manolio T, Ozenberger B, Hill S, Culfied M, Levy Y, Glazer D, Wilson J, Lawler Boughtwood T, Braithwaite J, Goodhand P, Birney E, North Responsibility. The American Journal of Human Genetics, 104, 13-20

Australian Genomics Health Alliance Acute Care Flagship (2020) Feasibility of Ultra-Rapid Exome Sequencing in Critically III Infants and Children With Suspected Monogenic Conditions in the Australian Public Health Care System. JAMA, 323, 2503-2511

Australian Genomics Evidence Summary (2020) Federa funding for clinical genomic tests. Available from www. australiangenomics.org.au

Australian Genomics Evidence Summary (2020) Internationa engagement. Available from www.australiangenomics.org.au

\section{Personal Response}

How many Australians can this project potentially benefit every year?

II About 2 million Australians, or 8 per cent, live with a rare disease. A disease is considered rare if it affects
fewer than five in 10,000 people. More than 7,000 rare diseases are life threatening or chronically debilitating. https://tinyurl.com/y3jyj3dm

More than 80 per cent of rare diseases are genetic. Due to their complexity they can take some time to diagnose, "diagnostic odyssey". Genomic testing is particularly successful in diagnosing these diseases.

Australia's Genomics Health Futures Mission aims to save or transform the lives of more than 200,000 Australians diagnosis and treatment. 